\title{
The effect of a sports program with nutritional supplement on some physical and physiological variables of cancer patients
}

\section{Introduction:}

Despite the remarkable progress in treatment methods since the early 20 th century, The proliferation of cancer cells is still the leading cause of death in cases of breast cancer, and it is known that the presence of any defect in cell adhesion is a common factor in most cancers in humans. Breast cancer is the most common cancer in women (1). Breast cancer is the second main cause of death in women. Breast cancer can begin in different parts of the breast (13). Weight gain is an important concern because Recurrence rates and survival in early-stage disease have been shown to be adversely affected by increased body weight in most studies ( 2 , $3)$. Diet and exercise can help breast cancer patients during chemical treatment $(4,5)$.

Breast cancer treatment is related with bone mineral density decreasing, which is a risk factor for osteoporosis and fragility fractures $(26,27)$. There was an interest in breast cancer patients by proceeding studies to identify the importance of diet and physical activity during the treatment of breast cancer $(9,10)$. Regular, appropriated exercises keeping health and fitness. Physical activity plays an important role not only in breast cancer treatment, but it extends to protection (17). considering the prevalence of breast cancer, the seriousness of that disease and its negative effects affecting the immune system, heart, blood, movement and strength of the arm, the researchers moved to apply a suggested program that includes sport and nutritional supplement to identify the effect of that program on some physical and physiological variables for breast cancer patients.

\section{Purpose:}

Identifying The effect of the suggested program on some physical variables (body weight, fist strength) for breast cancer patients.

Identifying The effect of the suggested program on some physiological variables (vital amplitude, pulse rate, vitamin D, hemoglobin, red blood cells, white blood cells) for breast cancer patients.

\section{hypothesis:}

There were differences between the pre and post measurement of the experimental group in the physical variables.

There are differences between the pre and post measurement of the experimental group in physiological variables.

\section{The research sample:}

The sample was chosen intentionally, 10 women who were attending the Medical Research Institute in Alexandria and who had breast cancer.

\section{Sample condition:}

1. Age from 35 years to 55 years.

2. Agreement and regularity.

3. The specialist doctor Agreement for the experiment procedures.

4. Women with breast cancer during chemotherapy first or second session. 


\section{The proposed program:}

The researchers reviewed the Arab and foreign scientific references and reference studies, then a proposed program consisting of a sports part and a healthy awareness in addition to a food supplement was designed as the experimental group was injected with vitamin D to avoid some side effects (lack of calcium, preventing the formation of new cancerous cells), and the program aims to To avoid lymphatic infiltration, and any complications during chemotherapy, and also helps to improve the health condition of patients so that you can complete the different stages of treatment, which is the proposed program that fits with the research sample according to their capabilities, health culture, and preparations, and $\mathrm{k}$ You psychological state, Also, it is appropriate for the therapeutic stage (chemotherapy) and the state of health with avoiding the side effects from the chemotherapy sessions (nausea, vomiting, diarrhea, and constipation), as well as taking into account the progression of exercises, not using resistance and strength exercises due to weak muscles of the bone to avoid any complications (dislocation, Fracture, rupture of the ligaments), and awareness of the importance of exposure to the sun to benefit from vitamin $\mathrm{D}$ while eating foods containing vitamin as well as intramuscular injection, taking into account the economic and social situation of patients during the development of the diet program, attention to eating some foods that contain vitamin D because of its uh It stimulates calcium and iron formation in the body, which in turn contributes to completing the chemotherapy stages and not stopping treatment due to the lack of these elements.

\section{General framework for program implementation:}

The program included (36) training units at the rate of (3) training units per week, for a period of (12) weeks. Each training unit took (30) minutes, which can be gradually increased throughout the period of implementing the program.

\section{Results:}

Table No. (1) Statistical indicators of physical and physiological measurements and the rate of improvement of the control group before and after the experiment.

\begin{tabular}{|c|c|c|c|c|c|c|c|c|}
\hline \multirow{2}{*}{$\begin{array}{l}\text { Statistical } \\
\text { indications } \\
\text { measurements }\end{array}$} & \multicolumn{2}{|c|}{$\begin{array}{c}\text { Before } \\
\text { measurement }\end{array}$} & \multicolumn{2}{|c|}{$\begin{array}{c}\text { After } \\
\text { measurement }\end{array}$} & \multicolumn{2}{|c|}{ Differences } & \multirow{2}{*}{$\begin{array}{c}\mathrm{T} \\
\text { value }\end{array}$} & \multirow{2}{*}{$\begin{array}{c}\text { Percentage } \\
\text { Improvement } \\
\%\end{array}$} \\
\hline & M & $\mathrm{SD} \pm$ & M & $\mathrm{SD} \pm$ & $\begin{array}{c}\text { Diff/.in } \\
\mathrm{M}\end{array}$ & $\begin{array}{c}\text { Diff/.in } \\
\text { SD } \pm\end{array}$ & & \\
\hline Weight $(\mathrm{kg})$ & 80.00 & 18.28 & 78.00 & $\overline{16.17}$ & 2.00 & 2.12 & 2.11 & 2.50 \\
\hline Fist strength $(\mathrm{kg})$ & 12.80 & 1.30 & 13.00 & 1.00 & 0.20 & 0.8 & 0.53 & 1. \\
\hline vital capacity $(\mathrm{mm})$ & 1620.00 & 83.67 & 1960.00 & 114.02 & 340.00 & 89.44 & $* 8.50$ & 20.99 \\
\hline Pulse rate $(\mathrm{p} / \mathrm{m})$ & 91.20 & 1.92 & 88.40 & 1.52 & 2.80 & 2.39 & 2.62 & 3.07 \\
\hline D vitamin (nano/gm) & 13.46 & 6.22 & 14.28 & 5.50 & 0.83 & 1.33 & 1.39 & 6.15 \\
\hline
\end{tabular}




\begin{tabular}{|l||c|c|c|c|c|c|c|c|}
\hline Hemoglobin (mm) & 11.14 & 0.61 & 10.48 & 0.37 & 0.65 & 0.61 & 2.42 & 5.87 \\
\cline { 2 - 8 } Red blood cells (mm) & 4.33 & 0.23 & 4.05 & 0.22 & 0.28 & 0.26 & 2.44 & 6.46 \\
\cline { 2 - 9 } white blood cells (mm) & 5.12 & 1.05 & 4.87 & 0.55 & 0.25 & 0.65 & 0.87 & 4.96 \\
\hline \hline
\end{tabular}

* Morale at the level of $0.05=(2.78)$

As illustrated in Table No. 1 of the statistical indicators for physical and physiological measurements and the rate of improvement of the control group before and after the experiment.

There were no statistically significant differences in all measurements except for the vital capacity. Values ranged between $(0.53$ to 2.62$)$ with an improved percentage (20.99\%).

Table (2) Statistical indicators of physical and physiological measurements and percentage of improvement for the experimental group before and after the experiment.

\begin{tabular}{|c|c|c|c|c|c|c|c|c|}
\hline \multirow{2}{*}{$\begin{array}{l}\text { Statistical } \\
\text { indications } \\
\text { measurements }\end{array}$} & \multicolumn{2}{|c|}{$\begin{array}{c}\text { Before } \\
\text { measurement }\end{array}$} & \multicolumn{2}{|c|}{$\begin{array}{c}\text { After } \\
\text { measurement }\end{array}$} & \multicolumn{2}{|c|}{ Differences } & \multirow{2}{*}{$\begin{array}{c}\mathrm{T} \\
\text { value }\end{array}$} & \multirow{2}{*}{$\begin{array}{c}\text { Percentage } \\
\text { Improvement } \\
\%\end{array}$} \\
\hline & M & $\mathrm{SD} \pm$ & M & $\mathrm{SD} \pm$ & $\begin{array}{c}\text { Diff/.in } \\
\mathrm{M}\end{array}$ & $\begin{array}{c}\text { Diff/.in } \\
\text { SD } \pm\end{array}$ & & \\
\hline$\overline{\text { Weight }(\mathrm{kg})}$ & 90.60 & 4.62 & 85.20 & 4.21 & 5.40 & 1.14 & $* 10.59$ & 25.96 \\
\hline Fist strength $(\mathrm{kg})$ & 14.40 & 1.52 & 19.00 & 1.58 & 4.60 & 0.55 & $* 18.78$ & 31.94 \\
\hline vital capacity $(\mathrm{mm})$ & 1620.00 & 130.40 & 2160.00 & 114.00 & 540.0 & 114.00 & $* 10.60$ & 33.33 \\
\hline Pulse rate $(\mathrm{p} / \mathrm{m})$ & 90.60 & 2.30 & 85.60 & 1.95 & 5.00 & 1.22 & $* 9.13$ & 5.52 \\
\hline D vitamin (nano/gm) & 14.07 & 4.77 & 18.33 & 3.55 & 4.25 & 1.33 & $* 7.17$ & 30.23 \\
\hline Hemoglobin $(\mathrm{mm})$ & 10.53 & 0.51 & 11.14 & 0.29 & 0.61 & 0.30 & $* 4.61$ & 5.78 \\
\hline Red blood cells (mm) & 4.66 & 0.26 & 4.91 & 0.07 & 0.25 & 0.25 & 2.23 & 5.41 \\
\hline white blood cells (mm) & 5.54 & 0.74 & 6.50 & 0.34 & .96 & 0.59 & $* 3.66$ & 17.33 \\
\hline
\end{tabular}

* Morale at the level of $0.05=(2.78)$

As illustrated in Table No. 2 of the statistical indicators of physical and physiological measurements and the percentage of improvement of the experimental group before and after the experiment: There are statistically significant differences in all measurements except for red blood cells. The values ranged between (3.66 to 18.78) while the red blood cells (2.23) with a percentage improvement (5.41). 


\section{Discussion:}

\section{The first hypothesis:}

It is clear from Table No. (1) and (2) that there are significant differences between the pre and post measurement in the physical variables (body weight and fist strength), which indicates a loss in body weight and an increase in the grip strength and the researchers refer this to the proposed program where exercises are performed Regularly with a diet that helps in losing weight, which reduces the risks during chemotherapy, as weight gain affects cancer patients negatively, and exercises in the proposed program led to increased strength of arm and wrist muscles. This is consistent with the results of the Kristen and Nicholas (2010) study that showed positive adaptations resulting from any physical activity, along with psychological and social aspects, in addition to body composition., which is characterized by increased or preserved muscle mass and low fat mass (17). The results of a Ben and others (2008) study also showed that exercise has beneficial effects on fitness and body weight (7). This is also consistent with the results of the Zora and others study (2011), the most important of which was that diet and exercise during chemotherapy for breast cancer patients had a positive effect on the body weight of the women in question (8). The results of the Claire et al. (2004) study indicate that exercise has beneficial effects in the long term physically and psychologically (11). that exercising protects against breast cancer and helps in maintaining a healthy weight $(23,24)$.It allows the importance of nutrition and physical activity in the treatment and prevention of cancer that the Global Cancer Research Fund, in partnership with the American Institute for Cancer Research, updated their report in 2007 to include food, nutrition, physical activity and cancer prevention (25).

\section{The second hypothesis discusses:}

From Table 1 and (2), it is clear that there are significant differences between the measurement before and after the measurement in the variables (vital amplitude, pulse rate, vitamin $\mathrm{D}$, hemoglobin, red and white blood cells) indicating increased immunity as a result of taking vitamin $\mathrm{D}$, which raises The performance of the immune system in addition to an increase in the number of white blood cells, in addition to an improvement in the circulatory system in the respiratory system, which represents a decrease in the average pulse rate, an increase in vital capacity, the number of red blood cells and hemoglobin, which in turn transports oxygen.

The most important of them is that diet and exercise during chemotherapy for breast cancer patients had a positive effect on lifestyle and blood, exercise and diet helped the body resist and recover (8). The results of Shrine Abdel Hamid's study (2013) confirmed that practicing yoga has benefits in reducing postoperative complications and improving quality of life (14). And hormonal effects on the risk of cancer, and therefore, the balance of food and sports play a vital role in increasing immunity.

Irwin (2015) and Thomas (2017) also indicated that exercise and nutrition positively affect joint pain and bone mineral density $(28,29)$.

\section{Conclusions and recommendations:}

\section{the conclusions:}


1. The suggested program had a positive effect on the physical variables (body weight, grip strength) of breast cancer patients.

2. The suggested program had a positive effect on the physiological variables (vital amplitude, pulse rate, vitamin $\mathrm{D}$, hemoglobin, red blood cells, white blood cells) for breast cancer patients.

\section{Recommendations:}

1- Applying and generalizing the suggested program on breast cancer patients because it has a positive physical and physiological effect.

2- adding anew career as a sports specialist and nutritionist in all neoplasm surgery institutes, as a treatment by nutrition and sports, as well as chemotherapy.

\section{References:}

1. Sestak I, Distler W, Forbes JF, Dowsett M, Howell A, Cuzick J. Effect of body mass index on recurrences in tamoxifen and anastrozole treated women: an exploratory analysis from the ATAC trial. J Clin Oncol. 2010; 28:3411-5. [PubMed: 20547990]

2. Courneya KS. Exercise in cancer survivors: an overview of research. Med Sci Sports Exerc. 2003; 35:1846-52. [PubMed: 14600549]

3. Payne JK, Held J, Thorpe J, Shaw H. Effect of exercise on biomarkers, fatigue, sleep disturbances, and depressive symptoms in older women with breast cancer receiving hormonal therapy. Oncol Nurs Forum. 2008; 35:635-42. [PubMed: 18591167]

4. Zora Djuric, Anne L. Weldon, Caroline R. Richardson, Kenneth. 2011; A Diet and Exercise Intervention during Chemotherapy for Breast Cancer Resnicow Open Obes J. 3: 87-97. doi:10.2174/1876823701103010087.

5. Chlebowski RT, Blackburn GL, Thomson CA, et al. Dietary fat reduction and breast cancer outcome: interim efficacy results from the Women's Intervention Nutrition Study. J Natl Cancer Inst. 2006; 98:1767-76. [PubMed: 17179478]

6. Johnson-Kozlow M, Rock CL, Gilpin EA, Hollenbach KA, Pierce JP. Validation of the WHI Brief Physical Activity Questionnaire among Women Diagnosed with Breast Cancer. Am J Health Behav. 2007; 31:193-202. [PubMed: 17269909]

7. Hemdan, Shimaa Badawy (2020); Biochemical study of survivin -31G/C promoter polymorphism in breast cancer, master degree, Faculty of Medicine, Sohag University.

8. Sheren Abdelhamed, Saad Elosh, Waleed Hammouda, 2013; The Effect of Hathayoga on the Immune System and mood state, in Female Breast Cancer Patients After Mastectomy, Theories \& Applications, the International Edition, (ISSN 2090-5270), Volume 3, No. 1 Pages (7 - 13) 
9. linda e. carlson, phd, michael speca, psyd, kamala d. patel, phd, and eileen goodey, msw Mindfulness-Based Stress Reduction in Relation to Quality of Life, Mood,Symptoms of Stress, and Immune Parameters in Breast and Prostate CancerPsychosomatic Medicine 65:571-581 (2003)

10. Christine Graf, Nicolas Wessely, 2010; Physical Activity in the Prevention and Therapy of Breast Cancer, PMCID: PMC3076351, 5(6): 389-394.

11. McNeely ML, Campbell KL, Rowe BH, Klassen TP, Mackey JR, Courneya KS. Effects of exercise on breast cancer patients and survivors: a systematic review and metaanalysis. CMAJ. 2006;175:34-41. [PMC free article] [PubMed] [Google Scholar]

12. Holmes MD, Chen WY, Feskanich D, Kroenke CH, Coldith GA. Physical activity and survival after breast cancer diagnosis. JAMA. 2005;293:2479-2486. [PubMed] [Google Scholar]

13. Hagstromer M, Troiano RP, Sjostrom M, Berrigan D. Levels and patterns of objectively assessed physical activity - a comparison between Sweden and the United States. Am. J. Epidemiol. 2010; 171:1055-64.

14. Troiano RP, Berrigan D, Dodd KW, et al. Physical activity in the United States measured by accelerometer. Med. Sci. Sports Exerc. 2008;40:181-8.

15. . World Cancer Research Fund/American Institute for Cancer Research. Food, Nutrition, Physical Activity, and the Prevention of Cancer: a Global Perspective. Washington, D.C.: AICR, 2007 Available from: AICR.

16. Saad F, Adachi JD, Brown JP, et al. Cancer treatment-induced bone loss in breast and prostate cancer. J. Clin. Oncol. 2008;26:5465-76.

17. Zaman K, Thurlimann B, Huober J, et al. Bone mineral density in breast cancer patients treated with adjuvant letrozole, tamoxifen, or sequences of letrozole and tamoxifen in the BIG 1-98 study (SAKK 21/07). Ann. Oncol. 2012;23:1474-81.

18. Irwin ML, Cartmel B, Gross CP, et al. Randomized exercise trial of aromatase inhibitorinduced arthralgia in breast cancer survivors. J. Clin. Oncol. 2015;33:1104-11.

19. Thomas GA, Cartmel B, Harrigan M, et al. The effect of exercise on body composition and bone mineral density in breast cancer survivors taking aromatase inhibitors. Obesity (Silver Spring). 2017;25:346-51. 